\title{
Empowerment of Mustaḥiq Zakat Model Towards Business Independency
}

\author{
Hamzah 1 \\ 1 faculty of Human Ecology, Institut Pertanian Bogor, West Java Indonesia. \\ Email: hamzahipb@yahoo.co.id
}

\begin{abstract}
:
Zakat has not been utilized intensively for the empowerment of mustahiq (zakat beneficiaries) in the form of productive economic business. The objective of the research was to analyze the level of mustahiqs' business independency; to analyze dominant factors that influenced mustahiqs' business independency, and to formulate an appropriate strategy to develop the mustahiqs' business independency. The research has been carried out on 254 mustahiqs in Bogor Regency (66 mustahiqs engaged in vegetable production at Cibungbulang District, 85 mustahiqs in skewer business at Tenjolaya District, and 103 mustahiqs in shoe business at Taman Sari District). A census sampling, data collection through a questionnaire, an in-depth interview and observation were carried out in 2013. Data were analyzed descriptively and statistically, using structural equation model (SEM). The results of the research showed that: (1) the strategy of mustahiq empowerment could be carried out through strengthening the intrinsic motivation, training technical aspects, assisting business capital and assistance. Empowerment can be conducted synergically by the government (arrangement, service, and counseling), private sectors/State Owned Business (BUMN), higher education and community.
\end{abstract}

Keywords: Zakat Beneficiaries Empowerment, Business Independency, Mustahiq Zakat.

\section{A. INTRODUCTION}

Poverty eradication programs that have been attempted and look for solutions by the Government and the private sector in Indonesia turns out to have not managed to eradicate poverty. The number of poor population in Indonesia, according to the Central Bureau of statistics (2013) as much as 28.07 million $(11,37 \%)$ from the Indonesia's total population of 240 million people. Empowerment of mustahiq through Fund grant of tithes and efforts of mentoring potentially mustahiq to develop so free from poverty. This means that zakat is not only distributed to the consumerist things only and only charity but rather for the benefit of a productive and educational in nature. According to Jaenal (2010), the efforts of empowerment for the poor (mustahiq) can be a solution, either by way of providing productive capital through zakat funds and mentoring.

Empowerment mustahiq efforts not limited to increase the scale of businesses and economies, but should also be aimed at learning for strengthening this aspect of knowledge, attitudes, and skills of the mustahiq. Existing environmental factors such as cultural values, religious, mutual cooperation, and solidarity must continue to be preserved in the mustahiq environment in order for the success of empowerment can be well achieved. 
Mustahiq empowerment course intensity not only in terms of their involvement in the activity of empowerment stages, but more mainstream in the management and utilization of zakat (venture funds) toward more sustainable, productive economy enterprise development such as that can be a source of income to his household.

This research aims to: (1) analyze the level of independence of the undertakings mustahiq. (2) analyze the dominant factors which affect the degree of independence of the mustahiq. (3) formulating the right strategy in improving the independence mustahiq effort.

The focus of this research is directed at the content and method of humanistic according to the needs for mustahiq business improvement and independence. Capital lending activities and mentoring of the mustahiq in this study is seen as a process of empowerment and education (learning) approaches, motivation, facilitation, and representation (Suharto, 2010). Kartasasmita (1997), Suharto (2005), Amanah (2007); Ife and Treseirero (2008) confirms that the institutional outreach and companion can realize an increase in the development of self-reliance. Mustahiq independent businessmen will be able to increase revenues (Marliati 2008), was grabbed progress and maintain effort sustainability (Utami, 2007) to manifest their prosperity and their families (Athoillah, 2013).

Independence mustahiq businesses are affected by many factors, such as the characteristics of the individual offender, social religious environment, counselor, institutional and the intensity of the empowerment itself (Sumardjo, 1999; Utami, 2007; Marliati, 2008; Hamida, 2003 and Fonjong, 2006). Self-sufficiency is an attitude which prioritizes ability of themselves in addressing the various issues in order to reach a goal, without closing themselves against various possibilities of mutually beneficial cooperation (Havigurst, 1972; Jejeebhoy, 1996; Sumardjo, 1999; Steinberg, 2001).

Self-reliance meant in this study are: (1) independence of the emotions (associated with the ability to control emotions such as hold prestige and a sense of shame, both on friends, family and community); (2) the intellectual independence (the ability to formulate problems, planning efforts, choosing the best innovation, control the power and creativity of an inhibitor factor); (3) the independence of act (capable of taking decisions and confidence).

Based on such thinking, conceptual thinking framework compiled research (Figure 1) is a process to improve the capacity and capability of the mustahiq, both seen from the aspect of mental attitudes, knowledge, and skills in order to make the community can determine choice of alternatives in solving the question of their life so that it becomes self sufficient in this endeavor together. In the process of empowerment of these efforts increased strength (power) that the community to have the power to progress and grow (Jim Ife, 1995; Sumodiningrat, 1999; Slamet, 2003; Sulistiyani, 2004; PNPM Mandiri, 2011). 
Figure 1. Research Conceptual Term of References

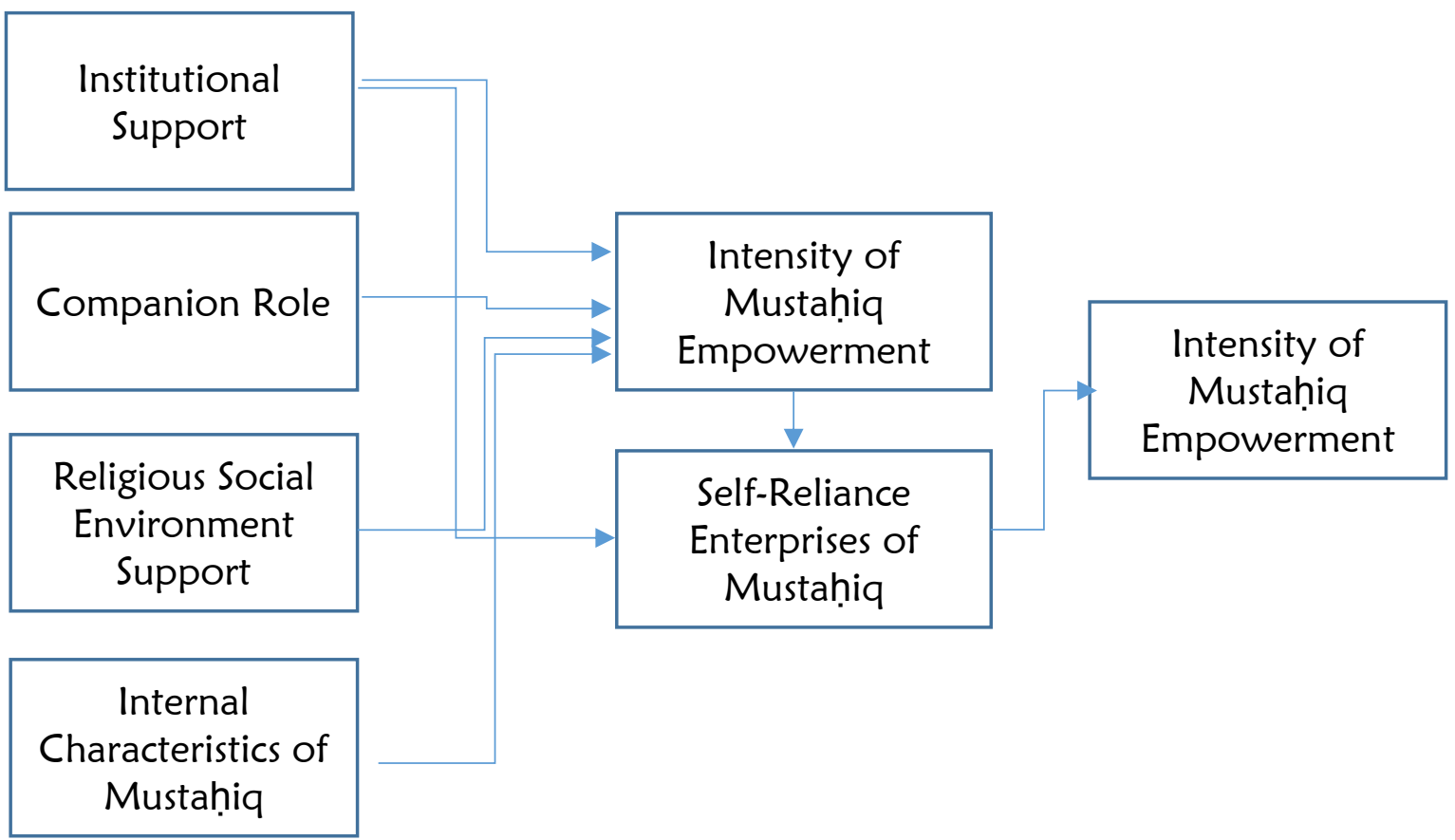

\section{B. METHODS}

The research was carried out with methods of census in three subdistricts in Bogor district with a total of 254 reponden mustahiq. The respondents mustahiq composed of vegetable businessmen production 66 mustahiq at Cibungbulang Subdistrict, 85 skewers makers mustahiq at Subdistrict Tenjolaya, and 103 moccasin business in the Taman Sari Subdistrict. Field research was carried out during the year 2013. Research instruments/questionnaire is built based on the concept of empowerment, and self-sufficiency. Test validity and reliability the questionnaire done to 30 musthiq in Bogor showed instrument which is valid and invalid. Data analysis with descriptive statistics, analysis of structural equation modeling (SEM) to analyze the factors that influence the level of independence of the undertakings mustahiq.

\section{RESULT AND DISCUSSIONS}

Mustahiq businessman relatively young with average age of 37.67 years, belongs on a productive age and educational level belongs to low (average educated primary and follows non-formal education as much as 1 time during the last three years). Mustahiq experience in business to an average of 6.9 years and business was assigned to be the main source of income for their households. Mustahiq is a high level of income, an average of Rp 2.170 thousand/month.

The role of companion is perceived as low but based on in-depth observation through the reading of the pledge fosters the intrinsic motivation of mustahiq belief that excited to have friendship at a meeting of the group, add to the family income, return the loans, and saving in addition to family interests also for charity, alms, as well as help mustahiq who run into trouble.

Institutional support (loan, informational support and marketing) at low to moderate category, except on loan capital. Relative capital loans are very easily accessible by mustahiq but information development related to business and marketing is still low, it is alleged to have trained field officers 
as an escort but turned out to be not effective, i.e. have less competence in empowerment. In the other hand the counselor serves more as the officer of loan collector, consequently the intensity of empowerment and joint venture independence still felt low. Religious social support belongs to the category of moderate to high except formal and non formal support of ruler who is still low in support of business mustahiq development.

Table 1. Description of Research Variables

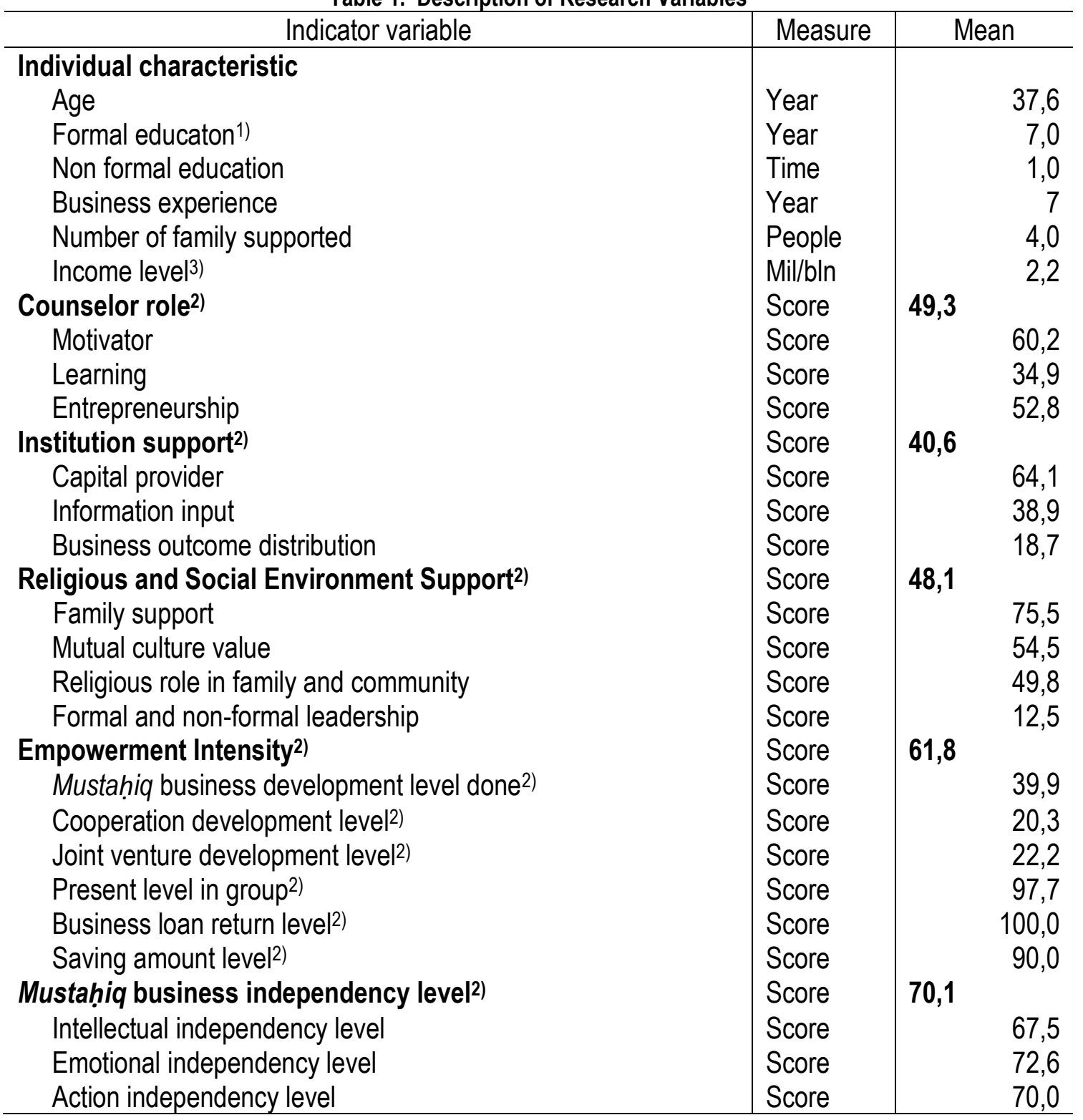

Note:

1) the numbers time of joining for last three years.

2) score category: low: $1 .<: 50 ; 2$. moderate: $51-75 ;$; 3. high: $>76$

3) income category 1 . low: $<1$.mil; 2 . moderate: $1.01 \mathrm{mil}-1.5 \mathrm{mil} ; 3 . \mathrm{high}:>1.6 \mathrm{mil}$.

The intensity level of the mustahiq empowerment are generally high in that category unless is still low on a joint development and joint ventures. The level of mustahiq self-reliance business, consisting of: intellectual, emotional independence and actionability, belongs in the category of high. It is based on in-depth observations that the said pledge to grow confidence in the independence of 
mustahiq individual endeavor but not yet on joint venture (groups). In fact mustahiq capacity of business and self tend to be static. This happens due to mustahiq tend to want to be in the safe zone in trying to (less daring risk). This situation led to the effort to run the less developed mustahiq.

As human beings are basically social have independence in this endeavor, not neutral and independent, but its existence was strongly influenced by its environment. According to Rulland (1984), confirmed that as social beings, humans are not truly autonomous, but the need and responsibility to self, the environment and his God. Research by Sumardjo (1999) in West Java in the self-reliance case disclosed that farmers self-reliance affected by internal factors (social status, personal qualities, communication, motivation and extrinsic motivation of and external factors (quality of the agricultural extension officers, commodity markets, urging outside the agricultural sector, penetration of non agricultural products, means of supporting agricultural development, resource availability information locally, the condition of the physical environment, and agricultural development policies. Increased capacity of self-mustahiq needs to take precedence on the ability to search and take advantage of opportunities, while the preferred business capacity on the ability development of business scale, particularly for marketing product, then focused on other elements.

\section{Factors that Affect the level of mustahiq zakat Self-reliance efforts}

SEM analysis of the results and test the suitability of the models, structural models of the fit obtained in the form of path diagrams (Figure 2). The internal characteristics of the mustahiq less affect the independence effort mustahiq for formal and non-formal education is low. Low levels of formal and non-formal education to make independence any mustahiq effort is still weak, particularly in terms of intellectual independence, self-sufficiency, and independence to act emotions. With a high degree of education a person will be able to independently, and be able to resolve the issue.

Indicator variables that characterize the dominant role of the companion importance are (a) learning and (b) entrepreneurship learning in terms of utilization of loans as the venture capital and develop entrepreneurial spirit. According to the Amanah (2007), the role of the counselor in the extension are able as (a) a facilitator, (b) a motivator, and (c) catalyst. The definition of a counselor as a facilitator, according to Sumardjo (2010), among others, is to evoke the need for change, use the relationship to change, diagnose problems, encouraging motivation for change, renewal action plan, keep the updates and prevents stagnation, as well as develop institutional capacity.

The support of influential religious and social environment is real and positive towards Self-reliance reflects a concerted effort by the indicators: (a) support of the family, (b) mutual cultural value, and (c) the religious role in the family and society. The leadership of formal and non-formal is an indicator of the negative variables support religious and social environment, because the reality in the field that shows lack of support of formal and non-formal development of the mustahiq joint venture. Likewise, the intensity of the empowerment affect directly on the independence.

The intensity of empowerment in the SEM test figure 2. effect on independence, because the strengthening of the joint venture, to build cooperation and develop joint ventures but low (table 1), this is because the intensity of empowerment has not resulted in independence of the joint venture.

The observations in the field and discussions with several program participants mustahiq turns out that self-reliance is a new business venture as individuals. There has been no attempt is done together or venture group. This is confirmed by information from the program manager, that 
empowerment does indeed recently addressed to the individual mustahiq, yet it came to the business of the group.

Figure 2. Structural Model (standarized)

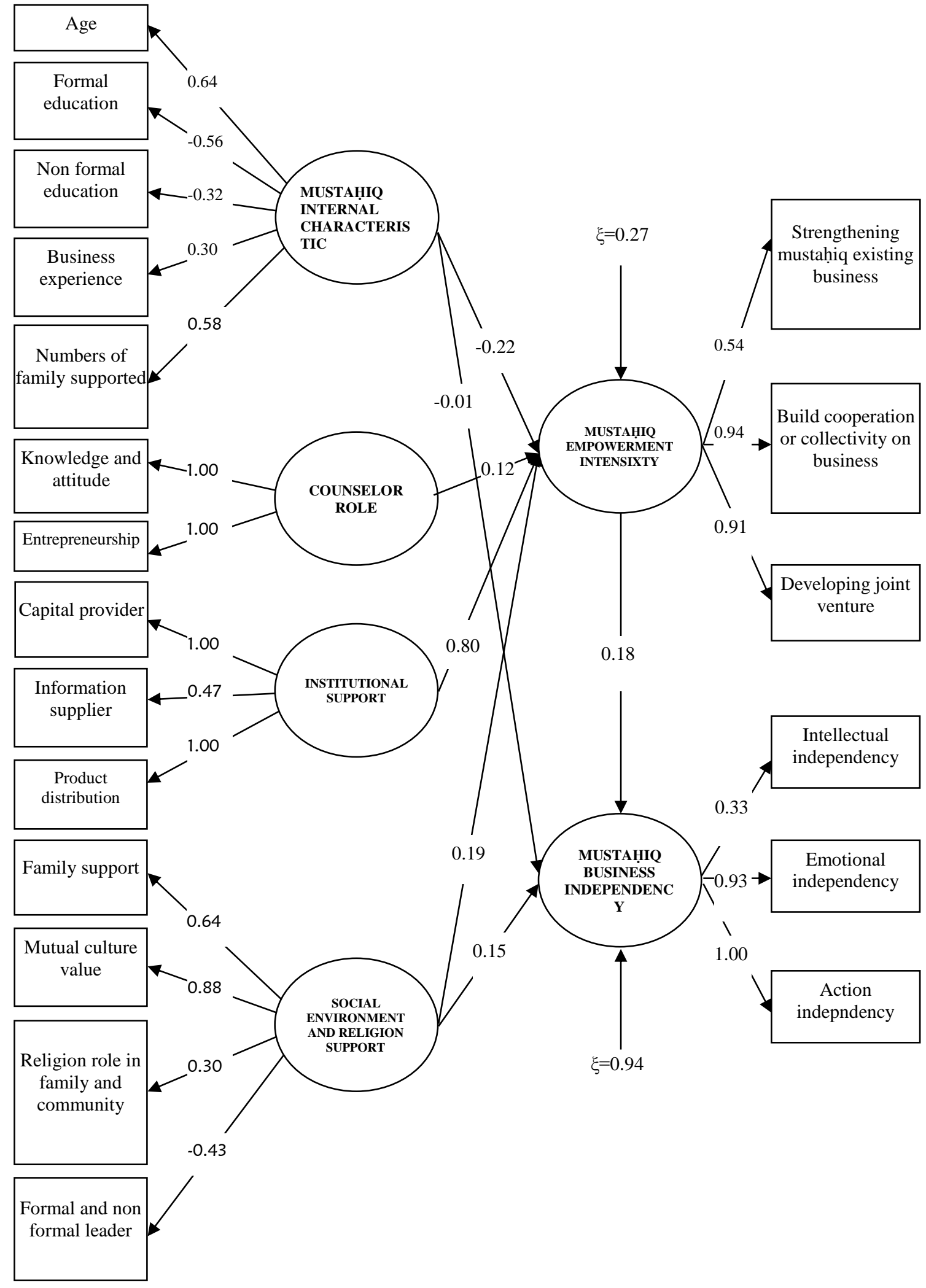

$\mathrm{RMSEA}=0.064, \mathrm{GFI}=0.96, \mathrm{AGFI}=0.91, \mathrm{CFI}=0.95, \mathrm{IFI}=0.95$ 


\section{Mustahiq Empowerment Strategy Towards Self-sustainability Business}

Figure 2 shows that the variables that directly affect mustahiq self-reliance business is the internal characteristics of the mustahiq, support social and religious environment, as well as the intensity of the empowerment of mustahiq business development and indirectly, through intensity variable in empowerment, mustahiq self-reliance business is also influenced by the role of companion and institutional support.

Thus the independent variables that must be considered in determining the empowerment strategy self-reliance mustahiq joint venture. To realize the independence of the joint venture mustahiq, then empowerment that conducted should be able to refine the indicators which are still weak, especially formal and non-formaeducation, mentoring and I leadership in formal and non-formal.

Theoretically as well as practices, mustahiq empowerment not enough with just giving money in the form of consumer or business capital assistance solely, but it requires sinergisme and alignment (mentoring and institutional) and strengthening of the important aspects of the self and the community of mustahiq, especially regarding aspects of awareness and empowerment in the intensity to increase the ability to utilize the funds to zakat. Zakat which can be collected in the long term should empower mustahiq to the level of recreating the independence business.

Mustahiq empowerment strategy towards self-sustainability effort can be done with the approach of the Input-Process-Output-learning outcomes-Impact. In general such empowerment can be divided into two stages, the first to realize the independence of individual business mustahiq, and the second phase of efforts to realize self-reliance group to do business together. With self-reliance groups then the joint venture can further developed so it can be expected that many mustahiq (recipient of the zakat) which will become muzakkī (Zakah payer/provider).

The first empowerment phase starts from mustahiq pledge to cultivate intrinsic motivation, then conducted training to enhance the technical capabilities of the mustahiq, which was strengthened with the impetus to seek to foster and enhance the mustahiq entrepreneurial spirit, backed by lending money for venture capital. Next step is the reinforcement of the group to generate a dynamic group, then carried out the development of a joint venture to strengthen the business group was formed. After that the strengthening of the joint venture will be capable of stimulate of business development group so formed a more powerful business group and independent.

The overall program of empowerment conducted embody the independence efforts ranging from individual mustahiq to materialize the independence group, expected to be a new program implementing the empowerment phase I and the subsequent phase. Specifically for programs that have been carrying out the empowerment phase I need to be continued with the empowerment subsequent phase.

The end result of the success of the empowerment program is expected to transform the condition of mustahiq that was originally only received assistance, can transform into a muzakkī is capable of giving assistance to others. 
Mustahiq empowerment strategy model towards self-sustainability efforts are presented in Figure 3 can be applied by the parties involved or interested in the empowerment of mustahiq, i.e. the Government, private, and community groups. The strategy with models expected, empowerment conducted will be done well and with a satisfactory product, results can change mustahiq (zakat beneficiaries) became a muzakkī (Zakah payer). In a schematic, mustahiq empowerment strategy towards self-sustainability effort is presented in Figure 3.

Figure 3. Scheme of mustahiq empowerment strategy

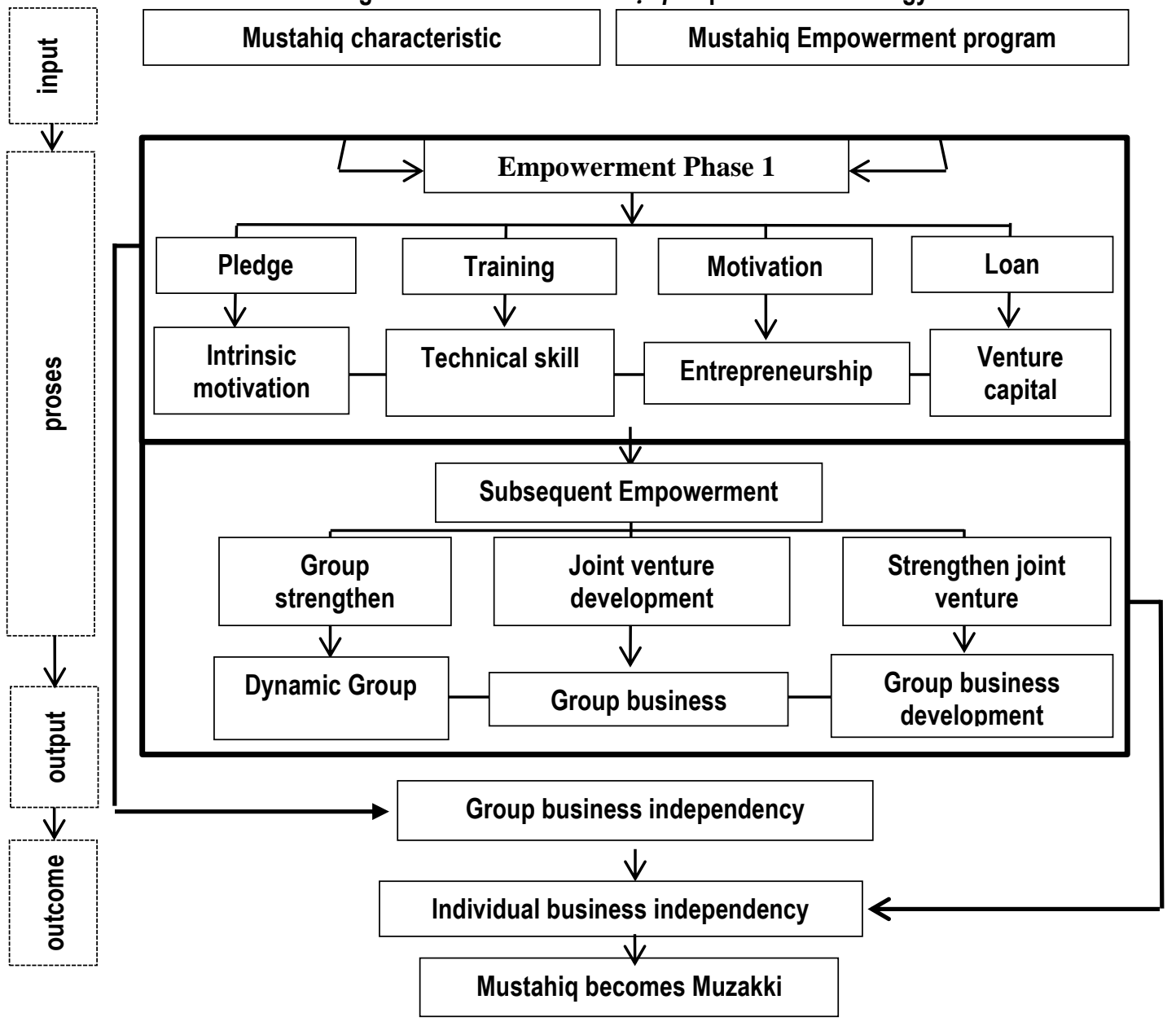

\section{CONCLUSION}

Real Condition, the situation showed that the level of independence of the mustahiq efforts are still at the level of self-reliance of less individividual businesses leading to independence of the group. The predominant factors that influence the independence of the level mustahiq effort i.e.: internal characteristics (formal education and non-formal, support from social environment (family support, mutual culture, values and religious role in the family and society), and the intensity of empowerment (strengthening of efforts, to build cooperation and develop joint venture). The empowerment strategy for mustahiq self-reliance efforts can be done with the approach of the Input-Process-Outputoutcomes-Impact. In general such empowerment can be divided into two stages, the first stage of improving the existing empowerment (empowering group one).The first empowerment stage starts from mustahiq pledge to cultivate intrinsic motivation, then conducted training to enhance the technical capabilities of mustahiq, strengthened or controlled by the existence of entrepreneur 
motivation to foster a spirit of entrepreneurship of mustahiq and supported by lending money to venture capital. The next step is the reinforcement of the group to generate a dynamic group, then carried out the development of a joint effort to strengthen the business group was formed. After that the strengthening of the joint venture will be capable of stimulate business development group so formed a more powerful business group and independent. The strategy with models expected, empowerment conducted will be done well and with a satisfactory product, results can change mustahiq became a muzakkī (payer of Zakah).

Considering the existence of the personal characteristics weakness of the mustahiq, among others in terms of capital, knowledge, motivation, and access marketing therefore the empowerment programs of mustahiq self-reliance efforts should start at the individividual effort. When individual business mustahiq have been in good shape and is profitable, and they have felt the benefits of business results, then the next stage of individual efforts should be encouraged and coordinated to be incorporated in the group to make it more powerful and easier in subsequent business development. In addition to the program manager or provider institution of Zakah, empowerment to the mustahiq can be done by Government, private/institutional STATE-OWNED ENTERPRISES, educational institutions, and community groups. Empowerment conducted by each party can run by itself, but of course the result will not be effective, so the alignment program between the parties is absolutely must be as good as possible. Training as a part in empowering mustahiq doesn't have to be done by the program empowerment mustahiq manager merely, but the Agency program managers can play a role in facilitating the course to another party if the mustahiq need the training organized by the institutional authorities, private/STATE-OWNED ENTERPRISES, colleges, and other community groups. The next stage is program development and strengthening empowerment mustahiq as a continuation of the previously existing programs but with refinements to the program in some way, or can be also a new program that hasn't been there before. In principle, whatever and however the empowerment program forms must be able to produce individual effort and then push it on the Group's efforts to materialize the mustahiq independence effort. 


\section{References}

Amanah. (2010). "Peran Komunikasi dalam Pemberdayaan Masyarakat". Jurnal Komunikasi Pembangunan, Vol. 08, No.1, pp. 1-19.

Athoillah, Mohamad Anton. (2013). "Zakat as an Instrument of Eradicating Poverty (Indonesian Case)". International Journal of Nusantara Islam, Vol. 1, No. 1, pp. 73-85, https://dx.doi.org/10.15575/ijni.v1i1.37.

Fonchingong. C.C and L.N. Fonjong. (2003). "The Concept of Self-Reliance In Community Development Initiatives In The Cameroon Grassfields", Nordic Journal of African Studies, 12 (2), pp. 196-219.

Hu, M W. (2010). SMEs and Economic Growth : Entrepreneurship or Employment. ICIC Express Letter, Volume 4, Number 6 (A), December 2010. Obtained from: http://mail.tku.edu.tw/humw/T2239.pdf [accessed on 24 May 2013].

Ismawan, Bambang. (2003). "Kemandirian, Suatu Refleksi”. Jurnal Ekonomi Pembangunan, Vol. 2 No 3 .

J., Ife, dan F., Treseirero. (2008). Community Development : Alternatif Pengembangan Masyarakat di Era Globalisasi. Translated by Sastrawan Manullang, Nurul Yakin and M.Nursyahid. Yogyakarta [ID]. Pustaka Pelajar.

Jaenal. (2010). "Pemberdayaan Masyarakat Berbasis Zakat". Jurnal Zakat \& Empowering Vol. 3.

Kartasasmita, Ginanjar. (1997). "Pemberdayaan Masyarakat: Konsep Pembangunan yang Berakar pada Masyarakat". Makalah pada Program Pascasarjana Studi Pembangunan Institut Teknologi Bandung [ID]: Institut Teknologi Bandung.

Marliati. (2008). "Pemberdayaan Petani Untuk Pemenuhan Kebutuhan Pengembangan Kapasitas dan Kemandirian Petani Beragribisnis (Kasus Kabupaten Kampar Provinsi Riau)". [Disertasi]. Bogor [ID]: Sekolah Pascasarjana Institut Pertanian Bogor.

Minarti. (2011). "Tolak Ukur Sharia Dalam Meneguhkan Perlawanan Atas Kemiskinan" Journal Indonesia Magnificence of Zakat,

Sadono, Dwi. (2008). "Pemberdayaan Petani, Paradigma baru Penyuluhan Pertanian di Indonesia". Jurnal Penyuluhan, Vol. 4 No. 1, pp. 65-74.

Slamet M. (2003). "Pemberdayaan Masyarakat" Di dalam, Ida Yustina dan Adjat Sudrajat, penyunting. Membentuk Pola Perilaku Manusia Pembangunan. Bogor [ID]: IPB Press.

Suharto E., (2005). Membangun Masyarakat, Memberdayakan Rakyat: Kajian Strategis Pembangunan Kes Sosial dan Pekerjaan Sosial. Bandung [ID]: Relika Aditama.

Sulistiyani, Ambar Teguh. (2004). Kemitraan dan Model-model Pemberdayaan. Yogyakarta [ID]: Gaya Media. 
Sumardjo. (1999). "Transformasi Model Penyuluhan Pertanian Menuju Pengembangan Kemandirian Petani (Kasus di Propinsi Jawa Barat)". [Disertasi]. Bogor [ID]: Program Pascasarjana Institut Pertanian Bogor.

Sumardjo. (2012). Review Refleksi Model Penyuluhan dan Inovasi Penyuluhan Masa Depan. Makalah dalam Seminar Nasional Membangun Penyuluhan Masa Depan yang Berkeadilan dan Menyejahterakan di Bogor [ID], dated 22 February 2012 .

Utami, Hamidah Nayati \& Sumardjo. (2006). "Faktor-faktor yang berhubungan dengan Kemandirian Pengrajin Kulit di Kab. Sidoarjo Magetan Jawa Tengah". Jurnal Penyuluhan, Vol. 2 No. 4, pp, 42-50. 
Empowerment of Mustahiq Zakat Model Towards Business Independency 